\title{
Adenylate Nucleotides and 2,3-Biphosphoglycerate Concentration in Erythrocytes of Growing Wielkopolska Stallions
}

\author{
M. SUSKA, E. SKOTNICKA ${ }^{1}$, W. DUDZIŃSKA ${ }^{1}$, W. OROWICZ, M. BRZEZINSKA
}

Department of Physiology, Faculty of Life Sciences, University of Szczecin, Poland

${ }^{1}$ Department of Biochemistry, Institute of Life Sciences, University of Szczecin, Poland

Received May 5, 2005

Accepted November 10, 2005

\begin{abstract}
Suska M., E. Skotnicka, W. Dudzińska, W. Orowicz, M. Brzezinska: Adenylate Nucleotides and 2,3-Biphosphoglycerate Concentration in Erythrocytes of Growing Wielkopolska Stallions. Acta Vet. Brno 2006, 75: 13-20.

The aim of this study was to examine the relationships between the concentrations of adenylate nucleotides (ATP, ADP, AMP), total nucleotide pool (TAN), adenylate energy charge (AEC) and 2,3-biphosphoglycerate (2,3-BPG) in the erythrocytes of young horses in the period of their rapid growth and development. The studies were conducted on 10 young Wielkopolska breed stallions for two years; Group A: 1-month-old, Group B: 3-month-old, Group C: 6-month-old, Group D: 1year-old, and Group E: 2-year-old. ATP, ADP and AMP concentrations in the erythrocytes were determined by HPLC. 2,3-BPG was determined using the Calbiochem USA kit.

We observed that erythrocyte ATP, ADP, AMP and TAN concentrations significantly decreased with age $(p<0.001)$, while 2,3-BPG concentration and AEC values significantly increased with age. A significant correlation between the ATP and TAN concentrations was found within all the examined groups $(p<0.05)$. A significant correlation was also found between ATP concentration and AEC values (except 12 month-old stallions). Moreover, an age-dependent negative correlation between ATP and 2,3-BPG $(\mathrm{r}=-0.81)$ was found.

The conclusion is that the adenylate energy charge and erythrocyte 2,3-BPG variables in the Wielkopolska stallions mainly depend on age, thus warranting the use of specific age-related reference values for this breed's foals.
\end{abstract}

Adenylate energy charge, 2,3-BPG, erythrocytes, stallions, age, breed

Characteristic compounds in the erythrocyte energy metabolism are the adenylate nucleotides (ATP, ADP, AMP) which undergo reversible changes in glycolysis (Ataullakhanov et al. 1996; Fokina et al. 2000). They are involved in the control of the correct shape of red blood cells, active transport through the membrane, phosphorylation of proteins and phospholipids, and the synthesis of glutathione and pyridine coenzymes (Arai et al. 1995; Brugnara 1997; Hoffman 1997; Sims et al. 2000; Bennett and Baines 2001).

The rate of glucose metabolism and the concentration of metabolites of the glycolytic pathway in the erythrocytes of various species of mammals, as well as concentrations of the adenyl ate nucleotides, are genetically determined (Harvey 1997). The haematological and biochemical variables also depend on species, breed and age (B rommer et al. 2001). Some exogenous and endogenous factors may also influence these values (Traut 1994; Suska 2001; Suska 2002). Human erythrocytes in the neonatal period have twice as high activity as the erythrocyte enzymes in adults (S eamen et al. 1980). It has also been observed that there are more young cells in the whole population of erythrocytes. This may result from more intense erythropoiesis and an increased enzyme activity (Bartosz 2000). These factors may induce changes in the adenylate nucleotide concentrations and in consequence influence the adenylate energy charge in equine erythrocytes in the neonatal and postnatal periods.

\footnotetext{
Address for correspondence:

Dr. Maria Suska

Department of Physiology, Institute of Life Sciences,

University of Szczecin

Piastów $40 \mathrm{~B}$

70-065 Szczecin, Poland
}

Phone/fax +48914441550

e-mail: suska@sus.univ.szczecin.pl

http://www.vfu.cz/acta-vet/actavet.htm 
Energy metabolism in erythrocytes is regulated by intracellular adenylate concentrations, especially ATP. Mathematic modelling suggests that during changes in ATP-consuming processes, adenylate metabolism may regulate the adenylate energy charge (AEC) of the cell (Joshi and Poison 1990).

The aim of this study was to compare the erythrocyte energy metabolism in the ontogenesis of Wielkopolska breed foals and 2-year-old stallions. The study was to determine the relationships between the ATP, ADP, AMP and 2,3-BPG concentrations on one hand, and the level of TAN and AEC values on the other, in the erythrocytes of young horses during growth and development. The relationship was also examined between the energy indices and the 2,3- BPG concentrations in the red blood cells of stallions of various ages.

\section{Materials and Methods}

Animals and management practices

The study was conducted for 2 years on a group of 10 young Wielkopolska breed stallions at 5 consecutive stages of development: 1-month-old foals (A), 3-month-old (B), 6-month-old (C), 12-month-old (D), and 24-month-old stallions (E). The horses came from environmentally clean areas, were not in training and were fed and treated equally. They were clinically healthy.

Blood sampling

In order to eliminate the influence of physical strain and circadian changes on some biochemical indices, $2 \mathrm{ml}$ of blood per heparinized test tube (250 IU heparin from Polfa Poland) was taken from the external jugular vein early in the morning before feeding. It was first sampled 4 weeks after birth (A) and then at the ages of 3, 6, 12 and 24 months (B, C, D, E). The blood was delivered to the laboratory in ice flasks and immediately analyzed.

\section{Laboratory evaluation}

Chemicals

The purines used as chromatographic standards were obtained from Sigma-Aldrich. HPLC grade acetonitrile was obtained from Merck. HPLC grade potassium dihydrogen orthophosphate, potassium chloride and tripotassium orthophosphate were obtained from Fluka Chemie GmbH. HPLC grade water was prepared using a Milli-Q (Millipore purification system). All HPLC solvents were filtered through $0.22 \mu$ m nylon filters (Supelco) before use.

\section{Instrumentation}

For the HPLC analysis, a Hewlett Packard chromatographic system was used. The HP series 1100 chromatographic system consisted of a quaternary pump system with a degasser and a continuous seal wash option (G1311A), a variable-wavelength detector (G1314) and a thermostatted column compartment (G1316A). The analytical column $(100 \times 4.6 \mathrm{~mm}$ LC) was packed with $18.3 \mu \mathrm{m}$ Hypersil BDS-C (Hewlett Packard). Samples were introduced using a Rheodyne 7725 injection valve equipped with a $20 \mu \mathrm{m}$ loop. Sample peaks were integrated and quantified using an HPLC chromatography data system operating on Chemstation Software for Windows 98 (Hewlett Packard).

HPLC separation of adenine nucleotides

All samples $(500 \mu \mathrm{l})$ were deproteinized with $500 \mu \mathrm{l}$ of $1.3 \mathrm{M}$ perchloric acid in $1.5 \mathrm{ml}$ Eppendorf tubes. Extract mixtures were centrifuged $\left(16000 \mathrm{~g}\right.$ for $10 \mathrm{~min}$, at $\left.4{ }^{\circ} \mathrm{C}\right)$. The supernatant $(600 \mathrm{~J} 1 \mathrm{l})$ was neutralized with approximately 60-90 $\mu \mathrm{l}$ of $3 \mathrm{M}$ potassium orthophosphate solution ( $\mathrm{pH}$ range of the sample at 6.3). The neutralized extract was centrifuged again and filtered through a nylon filter of $0.22 \mu \mathrm{m}$. The obtained clear filtrate was used directly for the HPLC assay or stored at $-80^{\circ} \mathrm{C}$.

Purine nucleotide determination

Concentrations of purine nucleotides: ATP, ADP, and AMP were measured by the HPLC method of Smolenski et al. (1990). Sample aliquots $(100 \mu \mathrm{l})$ were injected into the chromatograph column and the nucleotides were separated using a linear phosphate buffer gradient system at the flow rate of $0.666 \mathrm{ml} / \mathrm{min}$ (buffer A: $150 \mathrm{mM}$ $\mathrm{KH}_{2} \mathrm{PO}_{4}, 150 \mathrm{mM} \mathrm{KCI}$ adjusted to $\mathrm{pH} 6.0$ with $\mathrm{K}_{2} \mathrm{HPO}_{4}$; buffer B: $15 \% \mathrm{v} / \mathrm{v}$ solution of acetonitrile in buffer A). Peaks were detected by absorption measurements at $254 \mathrm{~nm}$. The composition of the mobile phase was controlled by a low-pressure gradient mixing device. The cycle time was $12.8 \mathrm{~min}$ between injections. The analytical column was maintained at constant temperature of $20.5^{\circ} \mathrm{C}$.

The adenine nucleotide concentrations ( $\mu \mathrm{M}$ in the whole blood) were calculated according to factors given in the method of Smolenski et al. (1990). Then the adenine nucleotide concentrations in the erythrocytes were calculated using the value of the packed cell volume (PCV).

The total adenylate nucleotides (TAN) and the adenylate energy charge (AEC) were calculated according to the formulas: 
$\mathrm{TAN}=[\mathrm{ATP}]+[\mathrm{ADP}]+[\mathrm{AMP}]$

$\mathrm{AEC}=\frac{1}{2} * \frac{[A D P]+2[A T P]}{[A T P]+[A D P]+[A M P]}$

The concentration of 2,3-BPG in the erythrocytes (mmol/IRBC) was determined using the Calbiochem (USA) reagents set by the method of Nygaard and Rorth (1969).

Statistical evaluation

The results are given as mean values $(\bar{x})$ and standard deviations (SD). The statistical significance of differences among the groups was determined with the monofactor analysis of variance using the evaluation of statistical significance of differences for many means and NIR Tukey's test (paired design). The Pearson's correlation coefficient was determined in all groups (according to the Statistica PL software) for all adenylate nucleotide, TAN and 2,3-BPG concentrations, as well as the value of the AEC (Stanisz 1998). The regression lines with marked values of correlation coefficients $[\mathrm{r}]$ were drawn for the significant relationships within the groups.

\section{Results}

The resulting concentrations of ATP and ADP in the erythrocytes were the highest in the youngest group (A), which were significantly different from all the other groups $(\mathrm{B}, \mathrm{C}, \mathrm{D}$, E) at $p<0.001$ (Table 1).

Table 1. Concentration of adenine nucleotides $(\mu \mathrm{M})$ in the erythrocytes of young Wielkopolska stallions

\begin{tabular}{|c|c|c|c|c|c|c|c|}
\hline & & $\begin{array}{c}\mathrm{A} \\
\mathrm{n}=12\end{array}$ & $\begin{array}{c}B \\
n=10\end{array}$ & $\begin{array}{c}C \\
n=10\end{array}$ & $\begin{array}{c}D \\
n=10\end{array}$ & $\begin{array}{c}E \\
n=10\end{array}$ & $\begin{array}{l}\text { Statistical } \\
\text { significance }\end{array}$ \\
\hline \multirow{2}{*}{$\begin{array}{l}\text { ATP } \\
\left(\mu \mathrm{M}_{\mathrm{RBC}}\right)\end{array}$} & $\bar{x}$ & 303.5 & 279.3 & 260.3 & 246.6 & 184.9 & \multirow{2}{*}{$\begin{array}{l}\mathrm{A}, \mathrm{B}^{* * *} ; \mathrm{A}, \mathrm{C}^{* * *} \\
\mathrm{~A}, \mathrm{D}^{* * *} ; \mathrm{A}, \mathrm{E}^{* * *} \\
\mathrm{~B}, \mathrm{C}^{* * *} ; \mathrm{B}, \mathrm{D}^{* * *} \\
\mathrm{~B}, \mathrm{E}^{* * *} ; \mathrm{D}, \mathrm{E}^{* * *}\end{array}$} \\
\hline & $\pm \mathrm{SD}$ & 8.6 & 6.5 & 5.8 & 20.6 & 22.8 & \\
\hline \multirow{2}{*}{$\begin{array}{l}\mathrm{ADP} \\
\left(\mu \mathrm{M}_{\mathrm{RBC}}\right)\end{array}$} & $\bar{x}$ & 50.4 & 45.1 & 40.8 & 36.0 & 28.8 & \multirow{2}{*}{$\begin{array}{l}\mathrm{A}, \mathrm{B}^{* * *} ; \mathrm{A}, \mathrm{C}^{* * *} \\
\mathrm{~A}, \mathrm{D}^{* * *} ; \mathrm{A}, \mathrm{E}^{* * *} \\
\mathrm{~B}, \mathrm{C}^{* * *} ; \mathrm{B}, \mathrm{D}^{* * *} \\
\mathrm{~B}, \mathrm{E}^{* * *} ; \mathrm{C}, \mathrm{D}^{* * *} \\
\mathrm{C}, \mathrm{E}^{* *} ; \mathrm{D}, \mathrm{E}^{* *}\end{array}$} \\
\hline & $\pm \mathrm{SD}$ & 2.1 & 1.4 & 1.7 & 4.7 & 3.5 & \\
\hline \multirow{2}{*}{$\begin{array}{l}\mathrm{A}^{\mathrm{MP}} \\
\left(\mu \mathrm{M}_{\mathrm{RBC}}\right)\end{array}$} & - & 9.9 & 8.9 & 7.7 & 6.7 & 5.7 & \multirow{2}{*}{$\begin{array}{l}\mathrm{A}, \mathrm{B}^{* *} ; \mathrm{A}, \mathrm{C}^{* * *} \\
\mathrm{~A}, \mathrm{D}^{* * *} ; \mathrm{A}, \mathrm{E}^{* * *} \\
\mathrm{~B}, \mathrm{C}^{* * *} ; \mathrm{B}, \mathrm{D}^{* * *} \\
\mathrm{~B}, \mathrm{E}^{* * *} ; \mathrm{C}, \mathrm{D}^{* *} \\
\mathrm{C}, \mathrm{E}^{* *} ; \mathrm{D}, \mathrm{E}^{*}\end{array}$} \\
\hline & $\pm \mathrm{SD}$ & 0.7 & 0.6 & 0.5 & 0.9 & 1.1 & \\
\hline
\end{tabular}

Legend: $\bar{x}$ mean; \pm SD standard deviation; ${ }^{* * *}(p<0.001) ;{ }^{* *}(p<0.01) ;{ }^{*}(p<0.05)$

The TAN in the erythrocytes of Group A foals was $363.9 \mu \mathrm{M} \mathrm{RBC}$, the highest among all the groups; however, AEC was significantly increasing with age (Table 2). The average value of AEC was the highest in Group D (0.915) and Group C (0.909), and the lowest in Group A (0.903). These results were significant at $p<0.001$ and the comparison of the AEC level between Group B (0.905) and Group C (0.909) was significant at $p<0.05$ (Table 2).

The content of 2,3-BPG in the erythrocytes of Group E was 5.7 $\mu \mathrm{MRBC}$, significantly higher than in any other group (A, B, C, D) (Table 2). The differences among the groups A, $\mathrm{B}, \mathrm{C}$ and $\mathrm{D}$ (paired design) were significant (Table 2). 
Table 2. Values of the adenylate energy charge (AEC), total adenylate nucleotide pool (TAN) as well concentration of 2,3-BPG $(\mathrm{mM})$ and ATP/ADP radio $(\mu \mathrm{M})$ in the erythrocytes of young Wielkopolska stallions

\begin{tabular}{|c|c|c|c|c|c|c|c|}
\hline & & $\begin{array}{c}\mathrm{A} \\
\mathrm{n}=12\end{array}$ & $\begin{array}{c}B \\
n=10\end{array}$ & $\begin{array}{c}C \\
n=10\end{array}$ & $\begin{array}{c}\mathrm{D} \\
\mathrm{n}=10\end{array}$ & $\begin{array}{c}\mathrm{E} \\
\mathrm{n}=10\end{array}$ & $\begin{array}{l}\text { Statistical } \\
\text { significance }\end{array}$ \\
\hline \multirow{2}{*}{$\begin{array}{l}\text { TAN } \\
\left(\mu \mathrm{M}_{\mathrm{RBC}}\right)\end{array}$} & $\bar{x}$ & 363.9 & 333.4 & 308.8 & 289.3 & 219.3 & \multirow{2}{*}{$\begin{array}{l}\mathrm{A}, \mathrm{B}^{* * *} ; \mathrm{A}, \mathrm{C}^{* * *} \\
\mathrm{~A}, \mathrm{D}^{* * *} ; \mathrm{A}, \mathrm{E}^{* * *} \\
\mathrm{~B}, \mathrm{C}^{* * *} ; \mathrm{B}, \mathrm{D}^{* *} \\
\mathrm{~B}, \mathrm{E}^{* * *} ; \mathrm{C}, \mathrm{D}^{* *} \\
\mathrm{C}, \mathrm{E}^{* *} ; \mathrm{D}, \mathrm{E}^{* * *}\end{array}$} \\
\hline & $\pm \mathrm{SD}$ & 8.3 & 6.3 & 5.2 & 23.7 & 24.6 & \\
\hline \multirow[t]{2}{*}{ AEC } & $\bar{x}$ & 0.903 & 0.905 & 0.909 & 0.915 & 0.908 & \multirow{2}{*}{$\begin{array}{l}\mathrm{A}, \mathrm{C}^{* * *} ; \mathrm{A}, \mathrm{D}^{* * *} \\
\mathrm{~B}, \mathrm{C}^{*} ; \mathrm{B}, \mathrm{D}^{* * *} ; \\
\mathrm{C}, \mathrm{D}^{*} ; \mathrm{C}, \mathrm{E}^{*}\end{array}$} \\
\hline & $\pm \mathrm{SD}$ & 0.003 & 0.003 & 0.003 & 0.006 & 0.006 & \\
\hline \multirow[t]{2}{*}{ ATP/ADP } & $\bar{x}$ & 6.0 & 6.2 & 6.4 & 6.7 & 6.5 & \multirow{2}{*}{$\begin{array}{l}\mathrm{A}, \mathrm{C}^{*} ; \mathrm{A}, \mathrm{D}^{* *} \\
\mathrm{~B}, \mathrm{D}^{*}\end{array}$} \\
\hline & $\pm \mathrm{SD}$ & 0.3 & 0.2 & 0.3 & 0.5 & 0.9 & \\
\hline \multirow{2}{*}{$\begin{array}{l}\text { 2.3-BPG } \\
\left(\mu \mathrm{M}_{\mathrm{RBC}}\right)\end{array}$} & $\bar{x}$ & 2.4 & 3.2 & 4.6 & 5.1 & 5.7 & \multirow{2}{*}{$\begin{array}{l}\mathrm{A}, \mathrm{B}^{* *} ; \mathrm{A}, \mathrm{C}^{* * *} \\
\mathrm{~A}, \mathrm{D}^{* * *} ; \mathrm{A}, \mathrm{E}^{* * *} \\
\mathrm{~B}, \mathrm{C}^{* * *} ; \mathrm{B}, \mathrm{D}^{* * *} \\
\mathrm{~B}, \mathrm{E}^{* * *} ; \mathrm{C}, \mathrm{D}^{* *} \\
\mathrm{C}, \mathrm{E}^{* *} ; \mathrm{D}, \mathrm{E}^{*}\end{array}$} \\
\hline & $\pm \mathrm{SD}$ & 0.2 & 0.3 & 0.2 & 0.4 & 0.5 & \\
\hline
\end{tabular}

Legend: - mean; \pm SD standard deviation;

${ }^{* * * *}(p<0.001)$;

${ }^{* *}(p<0.01) ;{ }^{*}(p<0.05)$

A negative correlation ( $r=-0.81)$ was found between the concentrations of ATP and 2,3BPG in all the groups of horses (Fig. 1). In all groups the ATP erythrocyte concentration was decreasing with age, but 2,3 BPG concentration was increasing (Table 2).

Moreover, significant positive correlations between ATP concentration and TAN, and between ATP and AEC, were found within each group (Table 3).

Table 3. Correlation coefficient ( $r$ ) between ATP levels in erythrocytes and nucleotide pool (TAN) and the adenylate energy charge (AEC) in the erythrocytes of Wielkopolska horses

\begin{tabular}{|c|c|c|c|}
\hline \multirow{2}{*}{\multicolumn{2}{|c|}{ Independent variable }} & \multicolumn{2}{|c|}{ Dependent variable } \\
\hline & & TAN $\mu \mathrm{M}_{\mathrm{RBC}}$ & $\mathrm{AEC}$ \\
\hline \multicolumn{4}{|c|}{ (Age group of stallions) } \\
\hline \multirow[t]{5}{*}{$\mathrm{ATP} \mu \mathrm{M}_{\mathrm{RBC}}$} & A - 1 month & $0.98^{*}$ & $0.94 *$ \\
\hline & B - 3 months & $0.99 *$ & $0.97 *$ \\
\hline & C - 6 months & $0.97 *$ & $0.90 *$ \\
\hline & D - 12 months & $0.99 *$ & 0.33 \\
\hline & E - 24 months & $0.99 *$ & $0.62 *$ \\
\hline
\end{tabular}

* significant difference $(p<0.05)$ 


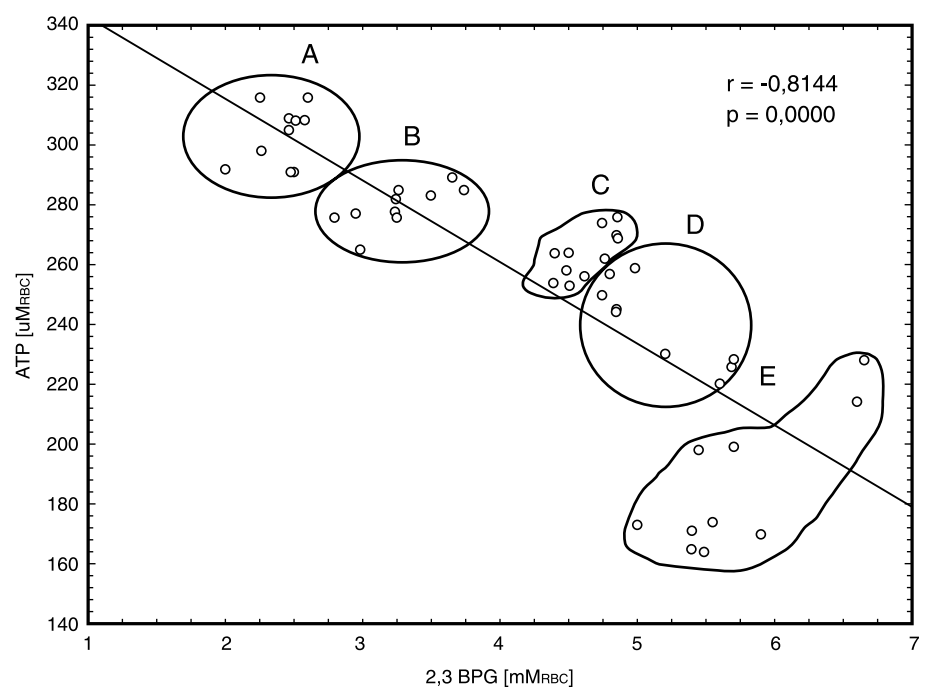

Fig. 1. Relationship between ATP concentration and 2,3-BPG level in the erythrocytes of stallions of Wielkopolska breed depending on their age, Age groups of horses: A 1 month, B - 3 months, C -6 months, D -12 months , E - 24 months

\section{Discussion}

The adenine nucleotides and 2,3-BPG play an important role in the erythrocyte energy metabolism. These compounds undergo reversible alternations in the glycolytic process and in the Rapaport-Lubering cycle, and their concentrations in the cells are influenced by various physiological factors in the erythrocytes of mammals, depending on species, breed and age of the studied animals (Mis eta et al. 1993, Harvey 1997). Brommer et al. (1996) confirm that the haematological and biochemical blood indices depend on the foal's age and directly on the regulatory enzyme activity in cell metabolism (in erythrocytes, the TAN value depends mainly on ATP concentration). Consumption of ATP during metabolism results in a release of considerable amounts of inorganic phosphate (Pi), which then leads to an increase in the erythrocyte concentration of AMP, because $\mathrm{Pi}$ and higher concentration of 2,3-BPG may inhibit AMP deaminase (EC 3.5.4.6) (A taullakhanov et al. 1996). We did not observe such changes occurring with age, because a decrease in ATP in our study was not accompanied by an increase in AMP.

A decrease in ATP concentration results in an increase of the phopshofructokinase I (EC 2.7.1.11) activity which regulates the rate of glycolysis (A taullak hanov et al. 1981). According to Schirmer and V ans (1990), a phopshofructokinase I activity increases when the ATP/AMP ratio decreases, and $\mathrm{Pi}$ concentration increases. We did not observe this effect in our study.

In the Wielkopolska foals (Groups A, B, C), ATP concentration decreased with age. However, the concentration of 2,3-BPG increased with age. The significantly higher ATP concentration in foals (A, B, C) compared to adult stallions (D) resulted in a significantly higher TAN (although TAN values were significantly changing with the age of stallions). Relationships among ATP, ADP and AMP concentrations determine the AEC value, which under physiological conditions is always 0.8-0.9 regardless of the generic features or the type of cell [Jozwiak, 1985]. AEC values were nearly constant, and equal to 0.903:0.915 in all groups (Table 2). Hence, the horses had a very high value of AEC, despite a low concentration of ATP in red cells. 
The significant decrease in ATP and TAN concentrations with the age of foals indicates varied glucose utilization, when compared to the 1- and 2-year-olds (D, E). Despite these differences, the efficiency of energy metabolism expressed in the ATP:ADP ratio, is nearly the same in all groups, except the significant difference between the 1-month-old foals and 1- and 2-year-old stallions (Table 2).

Despite the presence of some phosphorylated metabolites and their influence on the activity of various enzymes (Ataullakhanov et al. 1996; Fokina et al. 2000, Medeiros et al. 1982), the energy surplus was higher in the erythrocytes of the foals than in those of the 1- and 2-year-old stallions. A similar relationship was found in human red blood cells (Zachara 1967). It has been observed that the ATP erythrocyte concentration is $18 \%$ higher in children than in adults. Harvey and Kaneko (1975) indicate that in physiological conditions there are certain generic differences in the utilization of glucose in the process of glycolysis. According to these authors, erythrocytes in horses have a high hexokinase activity (EC 2.7.1.1) compared to other animals, which may influence the rate of metabolic utilization of glucose. However, the rate of glucose utilization in the red blood cells of horses is half the rate of humans and dogs and 2/3 of the cat's rate (Harvey and Kaneko 1975). These authors have also determined that in cats, dogs and humans, under physiological conditions about $6 \%$ of the glucose utilized by erythrocytes is metabolized in the phosphopentose pathway. In horses this value amounts to $13 \%$. The relatively low utilization of glucose in the process of glycolysis in horses compared to other mammals (Arai et al. 1995) is related to a relatively high percentage of glucose utilization in the phosphopentose pathway (Harvey and Kanek o 1975), and a relatively high concentration of intracellular 2,3-BPG. It results in a lower content of ATP in horses compared to other species (Table 1).

Mulquiney et al. (1999) showed that in physiological conditions the amount of glucose metabolized to 2,3-BPG in the human erythrocytes is about $19 \%$, and depends on ADP concentration. With a decrease in ADP concentration in erythrocytes, an increase in intracellular 2,3-BPG was observed in the studied foals as well as in the 1- and 2-year-old Wielkopolska stallions (Tables 1 and 2). A significant age-dependent negative correlation was observed between the ADP concentration and the level of 2,3-BPG in erythrocytes, and between ATP and 2,3-BPG concentrations (Fig. 1). A significant age-dependent increase in 2,3-BPG was observed, which indicated a gradual decrease in hemoglobin oxygen affinity during development and growth of the horses. It means that hemoglobin in that period had a greater ability to release oxygen into the developing tissues. During growth, a higher concentration of 2,3-BPG regulates hemoglobin oxygen affinity and indirectly determines the rate of metabolism of other cells (Bartos z 2000).

In conclusion, the adenylate nucleotide (ATP, ADP, AMP) and TAN concentrations, and the AEC values in the red blood cells of growing and developing Wielkopolska stallions, depend significantly on age. A very strong correlation between ATP and TAN concentrations was found within each age group. 2,3-BPG concentration in erythrocytes also depends on age; it was significantly lower in the foals compared with the 2-year-old stallions.

ATP concentration gradually decreases and 2,3-BPG increases with the age of horses. It enhances the regulation of hemoglobin oxygen affinity and positively influences the rate of metabolism in the tissues of growing and developing horses.

\section{Metabolismus adenosinu a koncentrace 2,3-bisfosfoglycerátu v erytrocytech během růstu u hřebců Velkopolského koně}

Cílem studie bylo zjistit vztah mezi koncentracemi adenosinových nukleotidů (ATP, ADP, AMP), celkovou energií obsaženou v nukleotidech (TAN), využitelnou energií a 2,3- 
bisfosfoglycerátem (2,3-BPG) v erytrocytech mladých koní v období rychlého růstu a vývoje. Studie byla provedena během 2 let na 10 hřebečcích Velkopolského koně. Skupina A: věk 1 měsíc; Skupina B: věk 3 měsíce; skupina C: věk 6 měsíců; skupina D: věk 1 rok a skupina E: věk 2 roky. Pomocí HLPC byly v erytrocytech stanoveny koncentrace ATP, ADP a AMP. Pomocí Calbiochem USA kit byl pak detekován 2,3-BPG. Zjistili jsme, že koncentrace ATP, ADP, AMP a TAN se s věkem signifikantně snižují $(p<0.001)$, zatímco koncentrace 2,3-BPG a hodnoty AEC se zvyšují. U všech zkoumaných skupin byla zjištěna signifikantní korelace mezi koncentracemi ATP a TAN $(p<0.05)$. Signifikantní korelace byla také zjištěna mezi koncentrací ATP a hodnotami AEC (s výjimkou hřebců ve věku 12 měsíců). Kromě toho byla zjištěna na věku závislá negativní korelace mezi ATP a 2,3BPG ( $\mathrm{r}=-0.81)$. Hodnoty AEC a 2,3-BPG v erytrocytech jsou závislé zejména na věku, takže umožňují využití specifických na věku závislých referenčních hodnot u hříbat Velkopolského koně.

\section{References}

ARAI T, WASHIZU T, SAGARA M, SOKO T, NIGI H, MATSUMOTO H, SASAKI M, TOMADO J 1995: Dglucose transport and glycolytic enzyme activities in erythrocytes of dogs, pigs, cats, horses, cattle and sheep. Res Vet Sci 58: 195-196

ATAULLAKHANOV FJ, VITVITSKY VM, ZHABOTINSKY AM, PICHUGIN AV, PLATONOVA OV, KHOLODENKO BN, EHRLICH LJ 1981: The regulation of glycolysis in human erythrocytes. The dependence of the glycolytic flux on the ATP concentration. Eur J Biochem 115: 359-365

ATAULLAKHANOV FJ, VITVITSKY VJ, KOMAROVA SV, MOSHAROV EV 1996: Energy dependent processes and adenylate metabolism in human erythrocytes. Biochemistry (Moscow) 61: 197-203

BARTOSZ G 2000: Erythrocytes. In: Dabrowski, Z (Ed.): Blood physiology. PWN, Warszawa, pp. 73-166

BENNETT V, BAINES AJ 2000: Spectrin and ankirin-based pathways: metazoan inventions for integrating cells into tissues. Am Physiol So 81: 1353-1391

BROMMER H, SLOET VAN OLDRUITENBORGH-OOSTERBAAN MM, KESSELS B 2001: Haematological and blood biochemical characteristics of dutch warmblood foals managed under three different rearing conditions from birth to 5 months of age. Vet Quart 23: 92-95

BRUGNARA C 1997: Erythrocyte membrane transport physiology. Curr Opin Hematol 4: 122-127

FOKINA KV, YAZYKOVA MY, DANSHINA PV, SCHMALHAUSEN EV, MURONETZ 2000: VI: Participation of glyceraldehyde-3-phosphate dehydrogenase in the regulation of 2,3-diphosphoglycerate level in erythrocytes. Biochemistry (Moscow) 65: 463-468

HARVEY JW, KANEKO JJ, 1977. Glucose metabolism of mammalian erythrocytes. J Cell Physiol 89: 219-224

HARVEY JW 1977: The erythrocyte: Physiology, metabolism, and biochemical disordes. In: KALENKO JJ, HARVEY JW, BRUSS ML (Ed.): Clinical biochemistry of domestic animals. Academic Press, New York London, pp. 125-142

HOFFMAN JF 1997: ATP compartmentation in human erythrocytes. Curr Opin Hemat 4: 112-115

JOZWIAK Z 1985: Participation of adenine nucleotides in the regulation of structure and properties of erythrocytes. Postepy Hig Med Dosw 39: 116-132

JOSHI A, PALSSON BO 1990: Metabolic dynamics in the human red cell. Part IV-Data prediction and some model computations. J Theor Bio1 142: 515-545

MEDEIROS LF, MEDEIROS LO, BERCIANO SANJURJO MA 1982: Energy metabolism in the erythrocytes of thoroughbred horses connected with perinatal physiological hemolysis. Comp Biochem Physiol [B] 71: 541-544

MISETA A, BOGNER P, BERENYI E, KELLERMAYER M, GALAMBOS C, WHEATLEY ND, CAMERON LJ 1993: Relationship between cellular ATP, potassium, sodium and magnesium concentration in mammalian and avian erythrocytes. Biochim Biophys Acta 1175: 133-139

MULQUINEY PJ, BUBB WA, KUCHEL PW 1999: Model of 2,3-diphosphoglycerate metabolism in the human erythrocyte based on detailed enzyme kinetic equations: in vivo kinetic characterization of 2,3diphosphoglycerate synthase/phosphatase using 13C and 31P NMR. Biochem J 342: 564-580

NYGAARD SF, RORTH M 1969: An enzymatic assay of 2,3-diphosphoglycerate in blood. Scand. J Clin Lab Invest 24: 399-400

SCHIRMER T, EVENS P, R 1990: Structural basis of the allosteric behaviour of phosphofructocinase. Nature 343: $140-145$

SEAMAN C, WYSS S, PIOMELLI S 1980: The decline in energetic metabolism with aging of the erythrocyte and its relationship to cell death. Am J Hematol 8: 31-42

SIEMS WG, SOMMERBURG O, GRUNE T 2000: Erythrocyte free radical and energy metabolism. Clinic Nephrol 53: 9-17 
SMOLENSKI RT, LACHNO DR, LEDINGHAM SJM, 1990. YACOUB MH 1990: Determination of sixteen nucleotides, nucleosides and bases using high performance liquid chromatography and its application to the study of purine metabolism in heart for transplantation. J Chrom 527: 414-420

STANISZ A 1998: A course in statistics based on the STATISTICA PL software. StatSoft Polska Kraków

SUSKA M 2000: The effect of sodium fluoride on the adenine nucleotide pool in erythrocytes of Wistar rats. Int J Occup Med Environ Health 14: 369-373

SUSKA M 2002: Energy metabolism of erythrocytes in lambs chronically exposed to fluorine compounds. Acta Vet Brno 71: 313-317

TRAUT TW 1994: Physiological concentrations of purines and pyrimidines. Mol Cell Bioch 140: 1-22

ZACHARA B, GREGER J 1967: The concentration of adenylate nucleotides and 2,3-BPG in the red cells of children and adults. Diag Lab 3: 107-11 